\title{
Insults - between dysphemisms and markers of emotional closeness
}

\author{
Roxana Pașca* \\ Faculty of Letters, Technical University of Cluj-Napoca, North University Centre, Str. Victoriei 76, 430122 Baia Mare, Romania
}

\section{Article info}

History:

Received June 26, 2021

Accepted July 6, 2021

Published August 18, 2021

Key words:

sociolinguistics

insults

dysphemisms

relevance theory

classification of insults

\begin{abstract}
The present investigative approach proposes an analysis of insults from a socio-, psycho- and pragmalinguistic perspective, aiming to reveal the complex character of this type of communication.

Given that insults, as reactive acts of speech, are dependent on both the intentions of the speaker and the way the receiver decodes the statement, we suggested a classification based on the illocutionary point (motivated insults - with negative or positive illocutionary point-and unmotivated insults) and on the propositional content (direct insults - within this category, we analyzed the lexical innovations generated by the Covid- 19 pandemic, especially the dysphemic use of the participle (substantivized) adjective covidat - and indirect insults).

Although the oral communication provides the necessary data for the manifestation of insults, in addition to the sequences selected from TV shows, we chose messages written on various social networking sites and excerpts from online forums. Under the protection of anonymity, users are uninhibited and they violate socially imposed linguistic norms without fear of being held accountable for their actions.
\end{abstract}

\section{Preliminary remarks}

The paper aims at investigating the verbal act of insult, generally considered a dysphemic category. Dysphemisms are a pragmalinguistic phenomenon having a lexical form that is inconsistent with sociocultural standards. In certain discursive contexts, dysphemisms have both positive effects-at the intraindividual level (emotional discharge) and at the interindividual level (ensuring group identity) — and negative effects (loss of status).

The use of insults does not imply a transgression of a normative code because people's affective manifestations are interpreted according to a sociocultural scenario. Thus, insults are an emotionally bivalent linguistic phenomenon: (1) as face-threatening acts, insults produce negative emotions (shame, humiliation); (2) as an index of emotional closeness, insults indicate membership and they are part of the linguistic norm accepted by all the members of the group.

Our research is based on the theoretical support offered by socio-, pragma- and psycholinguisticssee the speech acts theory (Searle, 1992); the relevance theory (Grice, 1957; Wilson, 2016); linguistic politeness and impoliteness (Brown \& Levinson, 1987; Kerbrat-Orecchioni, 1992, 2010, 2013)-and examines a series of insults taken from both the online environment (forums, social networks) and television shows or private conversations. Before the conversations transcribed, we presented the data that outline the communicative context: the place, the evolution of the communicative situation (prior to the fragment selected for analysis), the participants - age, gender, social or professional status - and the relationships between them.

*Email address: roxi.pasca@yahoo.com. 
Roxana Pașca

\section{Insults - complex speech acts}

\subsection{Co(n)text, participants and (inter)action}

Insults are forms of social interaction, which imply a particular discursive configuration and a situation of enunciation, whose most important elements are the participants, their mental state and socio-professional status. Insults appear, most frequently, in conflictual contexts and signal a communicative blockage. Any possibility of cooperation is cancelled ${ }^{1}$ due to the violation of the maxims of politeness. The speaker verbalizes his emotional state in a manner offensive to the interlocutor.

Insults are reactive speech acts triggered by a (verbal) behaviour or an attitude of the receiver, towards which the speaker expresses disagreement. In this context, we can notice a hierarchy between interlocutors, in terms of dominator/dominated, and the insult will be performed by the one in a higher social/discursive role.

The addresser of this speech act is in a dominant position ${ }^{2}$ (Kerbrat-Orecchioni, 1992, p. 72), as they are considered legitimate to destroy the public face of the target person, by identifying and disqualifying non-compliant behaviours: "the goal is to reduce to silence the interlocutor, taken off the interaction scene, for the benefit of the aggressor" (Ganea, 2007, p. 131). Placed in a lower position, the receiver ${ }^{3}$ can choose to counterattack or not. Therefore, insults are aggressive facework that threaten both the receiver and the speaker's face, through a possible counterattack or the negative social evaluation of the verbal action.

\subsection{Insults - a combination of speech acts}

Insults have a vocative character, being addressed by a sender to a target receiver, and a performative one because "by the simple fact that they are pronounced, they provoke, hurt and sometimes kill" (Bacot, 2007, p. 117).

On the other hand, Bourdieu (1982, p. 100) links insults to the social world theory. Like naming, they belong to acts of entitlement or dismissal. Used to negotiate the limits of what constitutes acceptable behaviour, this derogatory verbal act can serve as an instrument of social exclusion, and it confirms the rules of the recommended order.

Chevalier \& de Chanay (2009, p. 46-47) argue that insults are complex speech acts, which combine the assertive ( $B$ is associated with a devaluing trait and $A$ assumes the truth-value of the asserted sentence), the expressive (A displays a hostile attitude towards $\mathrm{B}$ ) and the directive (A requires a reaction from $\mathrm{B}$ ).

Therefore, the insult, as an illocutionary act, implies the following pattern:

- illocutionary point - to expose disagreement and emotion simultaneously;

- propositional content - connotative linguistic tools, which express an unfavourable assessment of a (non) verbal behaviour/attitude/state/belief;

- perlocutionary effect - the receiver decodes the offence, generating a reaction;

- "the essential condition for success" (see Ionescu-Ruxăndoiu, 2003, p. 33) - the condition of sincerity, which implies an authentic psychological state.

\footnotetext{
${ }^{1}$ Haverkate (1994, p. 18-79) considers that any insult requires a compensatory verbal act, an excuse, in order to restore the image of the offended person and the interactional balance.

${ }^{2}$ In addition, as they involve an affective dimension, insults are also acts of self-presentation (see the self-performed, Goffman, 2007, p. 252), portraying the speaker both as a person who displays their emotions (indignation, aggression, frustration), and an individual lacking in self-control.

${ }^{3}$ The communicative context of the insult often implies the presence of the receiver (individual or group), but the verbal act can be issued in absentia (see the referential or designative insult in Mateiu \& Florea, 2012, p. 121). This situation involves a third witness, who has three possibilities of reaction: (1) solidarity with the recipient of the insult; (2) supporting the issuer or (3) adopting a neutral position.
} 


\subsection{Decoding insults and relevance theory}

Grice (1957) considers communication a psychological phenomenon rather than a linguistic one, but, despite this approach, his analysis is based on the speaker's meaning, neglecting the receiver's level of understanding. The relevance theory is based on the principles enunciated by Grice $(1957)^{4}$, but the approach highlights the receiver's perspective and the inferential process in an attempt to decode the speaker's intention.

Wilson (2016, p. 82-83) defines two general notions, relevance in context and relevance to an individual. The aim is to define relevance not only for utterances but also for any external stimulus or internal mental representations, which can be a contribution to cognitive processes (not only utterances but also images, sounds, smells, thoughts or memories). Relevance is, therefore, "a property of the inputs of cognitive processes that makes them worth processing" (Sperber \& Wilson, 1986, p. 229). The criterion by which the selection of inputs is made is that of "maximizing the positive cognitive effects" (Sperber \& Wilson, 1986, p. 230), with a minimum processing effort ${ }^{5}$.

What makes a contribution relevant to an individual is that it activates the available contextual information to produce considerable cognitive effects, and what makes it maximally relevant is that it produces significant cognitive effects for less effort than any other alternative input available at that time. A stimulus becomes relevant if: (a) "it is relevant enough to be worth the audience's processing effort; (b) it is the most relevant one compatible with communicator's abilities and preferences” (Sperber \& Wilson, 2000, p. 231).

Some studies (see Lagorgette \& Larrivée, 2004; Brenes Peña, 2009) consider that, in the case of insult, the emphasis should not be on the speaker, but on the hearer; if the latter does not correctly decode the speaker's meaning, the speech act issued may not be considered an insult.

(1) The communicative context:

Place: the teachers' room;

Participants: A: f., co-worker with B; she has just got a haircut

B: $\mathrm{m}$.,

A: E ceva mai scurt decît mi-aş fi dorit eu. I-am zis că nu vreau scurt, că îmbătrîneşte. Totuşi, nu-i chiar așa rău. E uşor de intreținut.

B: Da. Chiar semeni cu cineva faimos. [mimează seriozitatea]

A: Serios? [zîmbește, evident încîntată de ceea ce aude] Cu cine?

B: Cu Lloyd. Îți lipsește numai un Harry.

A: Nu stiu cine e, dar mersi!

[A: It's a little shorter than I would have liked it. I told her I didn't want to be short, as it makes me look older. However, it's not that bad. It's easy to maintain.

B: Yes. You really look like someone famous. [B mimics seriousness]

A: Really? [A smiles obviously pleased with what she hears] With whom?

B: With Lloyd. All you need is Harry.

A: I don't know who that is, but thank you!]

4“The first is that a sentence meaning is a vehicle for conveying a speaker's meaning, where a speaker's meaning is an overtly expressed intention that is fulfilled by being recognised. The second is that a speaker's meaning cannot be simply perceived or decoded, but has to be inferred from her behaviour, together with contextual information. The third is that in inferring a speaker's meaning, the hearer is guided by the expectation that communicative behaviour should meet certain standards: for Grice, a cooperative principle and conversational maxims, and for relevance theorists, a presumption of optimal relevance" (Wilson, 2016, p. 79).

5 "As a result of constant selection pressures towards increasing cognitive efficiency, the human cognitive system has developed a variety of mental mechanisms or biases (some innate, others acquired) which tend to allocate attention to inputs with the greatest expected relevance, and process them in the most relevance-enhancing way" (Sperber \& Wilson, 1986, p. 260-266). 


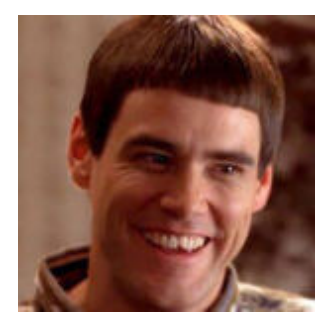

Figure 1: Jim Carrey (source: ficquotes.com)

The receiver correlates the propositional content with the contextual information she has available (the apparent seriousness of the speaker) and decodes as a compliment the first part of the speaker's remark because it produces significant cognitive effects (zîmbește, evident încîntată de ceea ce aude [A smiles obviously pleased with what she hears]), with less effort than the alternative input (Cu Lloyd. Iți lipsește numai un Harry [With Lloyd. All you need is Harry]). Alternative scenarios cannot be interpreted due to the lack of a common encyclopedic background ( $N u$ știu cine e, dar mersi! [I don't know who that is, but thank you!]). The illocutionary point is not achieved because the speaker compares his colleague's hairstyle with the actor Jim Carrey's haircut playing Lloyd (Fig. 1), in Dumb and Dumber. This statement is not relevant enough for the hearer "to be worth the cognitive effort" (Sperber \& Wilson, 2000, p. 231). Therefore, the cognitive process stops when it identifies an input that requires less effort (Chiar semeni cu cineva faimos [You really look like someone famous]), the adjective famous becoming an illocutionary marker of compliment.

\section{Classification of insults}

Insults are classified in numerous studies according to lexico-semantic criteria or by reference to taboos. Insults, as reactive acts of speech, are dependent both on the illocutionary point and on the hearer's cognitive processes of decoding the utterance. Therefore, we propose a classification from a sociopragmatic perspective.

\subsection{Illocutionary point-based taxonomy ${ }^{6}$}

\subsubsection{Motivated insults}

3.1.1.1. Negative illocutionary point - offending the target. This category is based on negative emotions - anger, frustration - insults are usually uttered in a conflictual situation. In this case, the insulter will produce standardized/conventional/stereotyped insults, easily accessible to correct decoding ${ }^{7}$. Din cauza stării sale psihice, locutorul apelează la cel mai la îndemînă termen ofensator, cu scopul evident de a leza imaginea publică a colocutorului:

(2) Stai dreq, covidatule, in banca ta și vezi să crapi, mai scăpăm de un pesedist hoț, incult și prost! [Fuckin' sit in your place, covidiot, and make sure you drop dead, at least we'll get rid of another thieving, uneducated, stupid supporter of the Social Democratic Party!] (replicaonline.ro);

(3) Mou, Rafilouu, faraoanee, covidatule, impielițatule, mai schimbăpampersu' hăla turcaziu, cămiroase a hurme marou păpartea cu gura lu' matale! [Hey, Rafila, you pharaoh, covidiot, and imp, change that greenish-blue nappy of yours, because it reeks of brownish stains around your mouth!] (activenews.ro);

\footnotetext{
${ }^{6}$ Mateo \& Yus (2000, p. 100) classify insults taking into account four variables: the type of propositional content, the intention of the speaker, the interpretation and the reaction of the target.

7 "Angry insults have less art and less complexity. They represent images from the heated heart rather than witty putdowns... Such abuse occurs either when the insulter has just experienced some major frustration or when the target has acted outside the legitimate boundary of behaviour" (Žegarac, 1998, p. 343).
} 
(4) Covidatule, tu nu ai acest simț, nici măcar ăla bun de la mă-ta, în cei 30 de ani de acasă [Covidiot, you don't have this sense, you don't even have the common sense from your mummy, despite the 30 years you've spent at home.] (stiridecluj.ro);

(5) Cornel Dinu, o nouă ironie pentru Ovidiu Popescu: „Covidel Popescu, posibil pilot doar de Formula XXX!" [Cornel Dinu, a new irony for Ovidiu Popescu: "Covidel Popescu, a potential Formula XXX driver only!] (fanatik.ro).

The Covid-19 pandemic has generated a series of lexical innovations (see the implicit contents in the jokes that appeared during this period, in Felecan \& Felecan, 2020), either through linguistic calques or internal means. Thus, we notice in the media the use of the participle-adjective ${ }^{\mathrm{a}}$ covidat, with a neutral meaning 'sick of Covid-19' (Luis Lazarus nu are COVID! Le-ar plăcea ăstora să aibă! Are pneumonie! 5 teste negative COVID și ei tot covidat îl consideră [Luis Lazarus does not have COVID! They would like him to have it! He's got pneumonia! Five negative COVID tests and they still consider him sick of Covid], ziaruldeiasi.ro). This lexeme can also acquire a dysphemic meaning, depending on the context.

In the above examples, participial adjectives become, by conversion, qualifying (depreciative) nouns with a vocative form, which function as unconventional offensive appellatives (Felecan, 2014, p. 176). This insult encrypts several symptoms of the disease, including loss of senses (smell, taste), extended to loss of common sense (tu nu ai acest simț, nici măcar ăla bun de la mă-ta, în cei 30 de ani de acasă [you don't have this sense, you don't even have the common sense from your mummy, despite the 30 years you've spent at home]).

It is also worth noting the play on words with a pejorative illocutionary point, based on the p honetic similarity between the anthroponym (Ovidiu) and the common noun (Covid), formed based on the same derivative pattern of the proper name: Ovidel-Covidel.

3.1.1.2. Positive illocutionary point - strengthening social ties. These ritual insults ${ }^{8}$ are not intended to offend the speaker but to mark a certain type of relationship between individuals in the same group, being an element of phatic communication, frequently used by teenagers (see Brenes Peña, 2009; Stenström \& Jörgensen, 2008). The cognitive effects depend on specific signs of the non-offensiveness of these insults and the interlocutor's accessibility to contextual information. Žegarac \& Clark (1999, p. 328) note that insults are used as a mode of action and the meaning of the seemingly offensive terms is irrelevant ${ }^{9}$ :

(6) Communication context: "Xtra Night Show", aired by the television channel Antena 1 on 27 February 2018, available online (May 2018);

Participants: Liviu Vîrciu [LV] and Andrei Ștefănescu [AȘ], very good friends.

LV: De unde săștie broasca ce-i ăla ocean? A avut și el [AȘ] 4 concerte. Ce „Sete de tine”? Că m-a... m-a luat și foamea. Dacă-și face matinal de weekend, îți dai seama cîte concerte are el cu Alb-Negru ăsta, dacă el face matinal de weekend. Concertele sunt în weekend.

AȘ: Matinalul e dimineața [întrerupere]

LV: Poi, unde pleci tu, prostul planetei, cum ai negociat tu contractu'ăsta? Duminică tu tre să fii la job.

${ }^{a}$ Although we chose the term covidiot for the translation to convey the meaning of the insult, the term is a participleadjective in Romanian.

${ }^{8}$ Fine (1981, p. 55-56) considers that interactional insults must be followed by other insults, being insults that build upon each other, increasing in a crescendo of abuse. [...] All speakers in this interaction are orienting their talk in the same direction... Friends are allowed and even expected to insult each other as a show of camaraderie. The nature of the insult is signalled by a smile or grin, permitting the target to accept the insult or even playfully act in accord with it. Participants in these interactions recognize that the overt meaning of the remarks is not what they really mean".

${ }^{9}$ Ritualic insults have the following characteristics: "(a) the insult is used as a mode of action, rather than for the transmission of thoughts; (b) the whole situation in which the exchange takes place consists in, and is largely created by what happens linguistically; (c) the mere meaning of the insult is almost irrelevant; rather, the insult used fulfils a social function; (d) this social function may be to overcome the strange, unpleasant tension caused by silence and/or to establish an atmosphere of sociability and personal communion between people" (Mateo \& Yus, 2000, p. 121). 
AȘ: Care job? Concertul este seara! Dacă n-a mai cîntat, dacă nu cîntă niciodată [întrerupere] LV: Care seară, băi, chelie be... [pauză], dacă ai sîmbătă seara, că era să zic chelie belită, mai bine că n-am zis. [rîde]

AȘ: Bine că n-ai zis, că ne făceam de rîs aicea. [rîde] $Z i$, nebunule!

LV: Sîmbătă noaptea, dacă te duci să cînți, cum te întorci tu dimineață? Ce te-nvîrte ăsta, băi! N-ai cum, bă, n-ai cum!

[LV: How would the frog know what an ocean is? He [ASS] has had 4 concerts. What's that "Thirsty for You"? I'm getting hungry already! If he gets to have his own morning show at the weekends, you can imagine how many concerts he's going to have with this Alb-Negru [BlackWhite] band of his, if he hosts weekend matinees. All the concerts are going to be at the weekends.

AȘ: The matinee is in the morning [break]

LV: Well, where are you going, you universal idiot, how did you negotiate this contract? You gotta be at work on Sunday.

AS,: What work? The concert is in the evening! If he hasn't sung in a while, if he never sings [break]

LV: What evening, you egghead... [pause], if your concert is on Saturday evening, I almost said peeled skullet, it's better I didn't say it. [laughter]

AȘ: It's good you didn't say it, we would have embarrassed ourselves. [laughter] Go ahead, lunatic!

LV: If you have to sing on Saturday night, how will you make it on the show in the morning? He's just pulling your leg! You can't make it, you just can't make it!]

This conversational exchange is based on a series of ironic remarks, culminating in phatic insults. Liviu Vîrciu calls his friend prostul planetei [universal idiot] and he hesitates to address the insult chelie belită [egghead], turning it into a possible thought spoken out loud, which arouses the amusement of the hearer, who chooses to react using the same lexical register (Bine că $n$-ai zis, că ne făceam de rîs aicea. [rîde] $Z i$, nebunule! [It's good you didn't say it, we would have embarrassed ourselves. [laughter] Go ahead, lunatic!]). His reply marks the acceptance of this type of relationship and the fact that the insults were decoded by the recipient according to the speaker's illocutionary point: emphasizing the emotional closeness between the participants in the dialogue. The speaker directs the discussion from specific, referential and subjective (Simbătă noaptea, dacă te duci să cînți, cum te întorci tu dimineață? [If you have to sing on Saturday night, how will you make it on the show in the morning?]), to general and indeterminate, involving the audience-which becomes part of the conversation accepting this type of relationship - by using the generic you $^{10}$ (Ce te-nvîrte ăsta, băi! [He's just pulling your leg!]) (see genericity vs referentiality in Zafiu, 2003).

\subsubsection{Unmotivated insults}

The speaker's intention is not to offend, but misinterpretations are caused by misunderstanding the extraverbal context or situations involving multiethnicity, as the speaker might not pay attention to some customs, habits, cultural or religious aspects of the interlocutors.

(7) Romanian President Klaus Iohannis talks about the Prime Minister's visit to the State of Israel: Această vizită pe care o face premierul și, se pare, și președintele Camerei Deputaților are cîteva ciudățenii: una este că nu au venit la discuții, nu a plecat doamna prim-ministru cu niciun fel de mandat din partea mea, deci a vorbit doar pentru Guvern, nu pentru România. Nu acest lucru $m$-a îngrijorat, ci secretomania cu care s-a aranjat această plecare. Nu am mai pomenit aşa ceva, să

\footnotetext{
10"The second person pronoun can therefore have the value of a generic person indicating a thematic role (agent, experi-
} menter, patient, beneficiary), obligatory human, collective and indefinite” (Zafiu, 2003, p. 235). 
anunțe seara tîrziu un premier al României despre o asemenea vizită externă, fără să se știe ce caută acolo. Așa, în vizită turistică, poate să plece oricine, oricînd. In ceea ce privește vizita președintelui Camerei Deputaților, a fost și un mai mare secret. S-a aflat că a plecat doar după ce a ajuns acolo. $\mathrm{Nu}$ știu care sunt dedesubturile acestei abordări, cine știe ce înțelegeri secrete face domnul Dragnea acolo cu evreii, dar sper că după revenire să aibă bunul-simț, să explice românilor ce au făcut acolo (dcnews.ro).

[The Prime Minister and the President of the Chamber of Deputies are on an official visit that has got some strange features: one is that they have not discussed it with me and the Prime Minister does not have any mandate from me, so she speaks only on behalf of the Government, not on behalf of Romania. It is not the only matter that worries me, as I am also concerned about the secrecy of this departure. I have not faced such a situation before involving a Romanian Prime Minister who announces an external visit late in the evening without knowing its purpose. Otherwise, anyone can go on a tourist visit at any time. As regards the visit of the President of the Chamber of Deputies, it was even a bigger secret. We found out he had left after he had arrived there. I don't know what the implications of this approach are (who knows what secret arrangements does Mr Dragnea make with the Jewish?), but I hope they will have the common sense to explain to the Romanian people what they did there.]

The speaker tries to highlight the inappropriate way the Romanian Government managed the official visit to the State of Israel without announcing the President. He insinuates the existence of secret agreements between Liviu Dragnea - the President of the Chamber of Deputies and the Social Democratic Party at the time-and the Israeli officials. Liviu Dragnea is known for his illegal business, and the fact that Israeli officials have been included in the same category, through a presumed alliance with Liviu Dragnea, generated strong reactions of this ethnic community. The terms used to describe the connection between the Romanian Prime Minister and the Israeli officials (strange features, secrecy, big secret, secret arrangements) put their discussions in a bad light.

The speaker had to apologize to those who felt insulted, explaining that his statement was, in fact, a rhetorical question, that was intended to highlight the inappropriate nature of the visit. Klaus Iohannis justifies the erroneous interpretation of his discourse as being anti-semitic by the positive relations he has established within the Jewish community. The previous statement is marked by inconsistencies and lack of communication between the Government and the President: Being accused of anti-Semitism seems ridiculous to me. I have been praised and honoured by several Jewish associations, and I am sure everyone knows that the bilateral relations between Romania and the State of Israel have been excellent since the founding of the modern State of Israel. I certainly did not use pejorative words in my statement, but if someone feels offended, I apologize (ziare.com).

\subsection{Propositional content-based taxonomy}

\subsubsection{Direct insults}

This type of insult does not involve an inferential process on the part of the receiver, and it uses derogatory terms to disqualify the target:

(8) Communicative context: Tudorel Toader, Minister of Justice, made a pronunciation mistake that generated a series of jokes in the media ${ }^{11}$; Cheloo l-a „ievaluat” pe Tudorel: are două fețe. Ambele de prost! [Cheloo "ievaluated” Tudorel: he has got two faces. Both stupid!] (kmkz.ro).

\footnotetext{
11 “Dilema Veche magazine counted the grammatical errors in the report on Tudorel Toader's 'ievaluation' of activity in the National Anticorruption Directorate, and found an average of 10 mistakes per page" (kmkz.ro); "Tudorel Toader, 'ievaluated' by deputies” (cotidianul.ro); “Tudorel Toader’s ‘self-ievaluation’ before his resignation” (europalibera.org).
} 


\subsubsection{Indirect insults}

Indirect insults imply a complex inferential process because "they are often obtained by performing a verbal act through the linguistic means of another" (Zvirid, 2013, p. 118). The use of lexical structures specific to another category of speech acts compels the hearer to make an interpretive effort to decode the speaker's communicative intention.

(9) Mai uşor cu posturile, preacucernicilor, că n-o să mai încăpeți în Merțane și va trebui să mergeți cu autobuzul! Țin posturile cu sfințenie și treaba asta le dereglează fengșuiu' intestinal? [Easier with fasts, you pious Fathers, because you won't fit into your Mercedes anymore and you will have to travel by bus! Is their fasting ritual so strict that it disturbs their intestinal Fengshui?] (kmkz.ro);

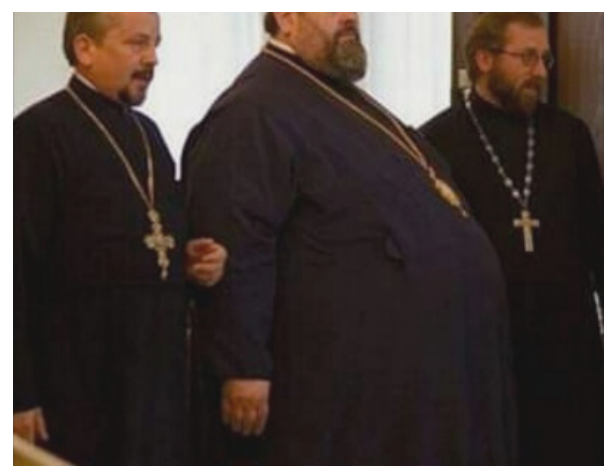

Figure 2: Source: kmkz.ro.

The irony implies a negative attitude, expressed through a seemingly appreciative propositional content. Simpson (2003, p. 22-28) considers that irony functions as an echo interpretation of a previous statement. The receiver must make certain assumptions based on the relevant knowledge he has about the speaker and the context to reach the ironic intention of the enunciator. In this example, the inferential process is based on a graphic context, the structure [text + image] representing the interference between verbal irony and the visual element. The image helps the receiver detect the ironic nature of the question Is their fasting ritual so strict?, which is in opposition to the physical appearance of overweight priests.

(10) Communicative context: "Happy Hour" (TV show), aired by the television channel PRO TV, available at online (December 2017);

Participants: Cătălin Măruță [CM], the show’s moderator, and Vadim Tudor [VT]. Vadim Tudor has a conflict with Oana Zăvoranu.

VT: Zăvoranca asta e o japiță de primă clasă!

CM: Dar știți că Oana Zăvoranu este și actriță?

VT: A! Este actriță? [ridică din umeri și își dă ochii peste cap] Da-n ce-a jucat, băi?

$\mathrm{CM}:$ A jucat in telenovele.

VT: In ce a jucat, băi, in Ciopîrțilă Cascador? In ce a jucat? Arici pogonici? În ce a jucat, măa, că scrie "miau” ca pisica? E un nimeni, dom'le, nu-mi spune tu mie!

[VT: Zăvoranca is a first-class good-for-nothing!

CM: Do you know that Oana Zăvoranu is also an actress?

VT: Oh! Is she? [He is shrugging his shoulders and rolling his eyes] What movies has she played in, man?

CM: She has played in soap operas. 
VT: Like what? Ciopîrțilă Cascador ${ }^{\mathrm{b}}$ ? Like what? Arici pogonicic ? What movies has she played in, man? She spells "youre" like a cat. She's a nobody! Don't you dare say otherwise!]

The TV presenter's informational act triggers the guest's reaction. Vadim Tudor disqualifies Oana Zăvoranu from a professional viewpoint by not recognizing her activity as an actress (A! este actriță? [Oh! Is she (an actress)?]). The disguised astonishment ${ }^{12}$ is reinforced at the level of nonverbal communication (ridică din umeri şi işsi dă ochii peste cap [he is shrugging his shoulders and rolling his eyes]). Vadim Tudor asks for and brings in (ironic) clarifications on the woman's qualification. The titles mentioned by the guest (În ce a jucat, băi, în Ciopîrțilă Cascador? In ce a jucat? Arici pogonici? [Like what? Ciopîrțilă Cascador? Like what? Arici pogonici?]) can be decoded as an insult because they refer to animated films (Ciopîrțilă Cascador, directed by Iulian Hermeneanu) and nursery songs (Arici pogonici), disregarded by the speaker. His ironic intention is highlighted by the remark În ce a jucat, mă, că scrie „miau” ca pisica? E un nimeni, dom'le, nu-mi spune tu mie! [ What movies has she played in, man? She spells "youre" like a cat. She's a nobody! Don't you dare say otherwise!]. The active or passive audience must recover the implicit content:

Rating: Zăvoranca asta e o japiță de primă clasă! [Zăvoranca is a first-class good-for-nothing!] Counter-opinion: The TV presenter apparently restores the public image of the attacked person (Dar știţi că Oana Zăvoranu este și actriță? [Do you know that Oana Zăvoranu is also an actress?]).

Justification: The speaker provides the arguments intended to act persuasively on the receivers, in order to legitimize the hypothesis stated above. This process is based on a causal relationship. Oana Zăvoranu is an uneducated person (scrie „miau” ca pisica [she spells “youre” like a cat]). $\Rightarrow$ If Oana Zăvoranu is an uneducated person, she cannot star in cinematic masterpieces, but only in worthless movies (În ce a jucat, băi, în Ciopîrțilă Cascador? In ce a jucat? Aricipogonici? [Like what? Ciopîrțilă Cascador? Like what? Arici pogonici?]). $\Rightarrow$ If the movies she acted in are worthless, Oana Zăvoranu is a worthless person;

Conclusion: Oana Zăvoranu is a worthless person (E un nimeni, dom'le, nu-mi spune tu mie! [She's a nobody! Don't you dare say otherwise!]).

(11) Communicative context: Romanian Parliament; the conversation is available online (January 2020);

Participants: Cosette Chichirău [CC], USR deputy, and Șerban Nicolae [ȘN], PSD senator;

Communicative situation: Cosette Chichirău [CC] states that Șerban Nicolae [ȘN] is just a driver, and his professional advancement is not based on meritocracy because he does not have the required studies.

CC: Domnul Șerban Nicolae insultă tot poporul român și fură împreună cu grupul său infracțional organizat.

ȘN: Ia, scrieți o plîngere penală! Căutați un coleg alfabetizat și scrieți o plîngere penală la adresa mea, cu ce am furat eu! Căutați un coleg care a terminat clasa a doua.

[CC: Mr Șerban Nicolae insults the Romanian people, and he steals with his organized criminal group.

ȘN: Go ahead, write a criminal complaint! Find a literate colleague and file a criminal complaint against me with everything I have stolen! Look for a colleague who has graduated the second grade.]

\footnotetext{
${ }^{\mathrm{b}}$ This is the title of an animated film.

${ }^{c}$ This is the title of a nursery song.

${ }^{12}$ Vadim Tudor was well aware of the woman's professional activity. He talked about Oana Zăvoranu's work when he presented her as a member of PRM (a political party whose president was Vadim Tudor).
} 
The accusations made by Cosette Chichirău through two performative verbs trigger a negative reaction from the target person, who uses the insinuation mechanisms to disqualify the USR deputy. The directive act, having the imperatives find și write as center, implies an inferential process on the part of the receiver: Cäutați un coleg alfabetizat și scrieți o plîngere penală la adresa mea, cu ce am furat eu [Find a literate colleague and file a criminal complaint against me $\Rightarrow$ You are not literate and cannot write, therefore you need someone else's help to draft a criminal complaint; Căutați un coleg care a terminat clasa a doua. [Look for a colleague who has graduated the second grade.] $\Rightarrow$ You didn't graduate the second grade.

(12) Întrebare: De ce se ține Timmermans de buzunar cînd stă lîngă Dragnea? Răspunsuri: (1) E foarte bine informat! (Paul Lupan); (2) Iar rîdeți degeaba. Vă asigur că și-a cusut buzunarele de acasă, e doar un gest din reflex. (Bogdan Iordache); (3) E Photoshop, de fapt, e mîna lui Dragnea! (Petrar Vali); (4) Ca să nu-i bage Dragnea din reflex 10 lei! (Alexandru Macarenco); (5) Știe că Dragnea își face bine meseria (Cordus Ion) (kmkz.ro);

[Question: Why is Timmermans holding his pocket when he is standing next to Dragnea?]

Answers: (1) He is very well informed! (Paul Lupan); (2) Don't laugh! I assure you he sewed his pockets at home. It's just a reflex gesture. (Bogdan Iordache); (3) It's Photoshop. In fact, that is Dragnea's hand! (Petrar Vali); (4) He keeps his hand like this so that Dragnea doesn't put 10 lei inside out of the reflex! (Alexandru Macarenco); (5) He knows Dragnea does his job well (Cordus Ion).]

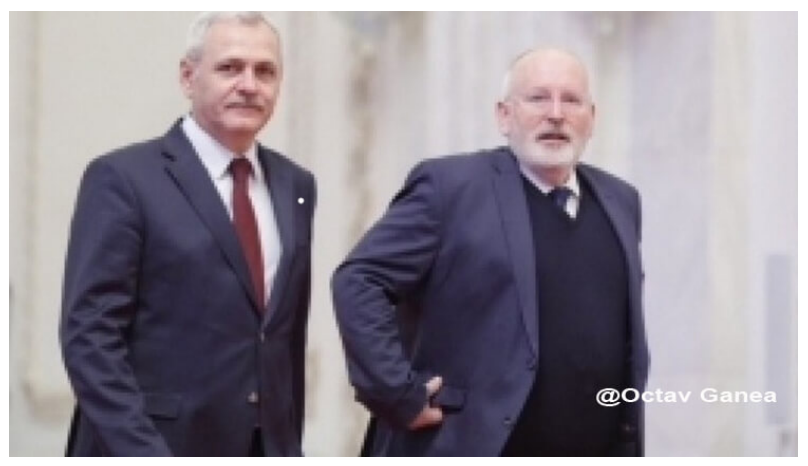

Figure 3: Source: kmkz.ro.

To correctly decode this complex [image + text], the reader must have certain contextual information to infer the conversational implicature. Liviu Dragnea was the president of the Social Democratic Party, and he is accused of fraud and corruption in numerous criminal cases. The ironic question De ce se tine Timmermans de buzunar cînd stă lîngă Dragnea? [Why is Timmermans holding his pocket when he is standing next to Dragnea?] (implying: Is he afraid of being robbed?) generates a series of answers that contain the same type of subtext:

1. E foarte bine informat! [He is very well informed!] = Timmermans knows that Liviu Dragnea is accused of fraud, therefore he steals. Timmermans knows that Liviu Dragnea is a thief.

2. Iar rîdeți degeaba. Vă asigur că și-a cusut buzunarele de acasă, e doar un gest din reflex. [Don't laugh! I assure you he sewed his pockets at home. It's just a reflex gesture.] = This answer derives from the previous one: Timmermans is well informed. He knows that Dragnea is a thief, so he took precautions when meeting him.

3. E Photoshop, de fapt, e mina lui Dragnea! [It's Photoshop. In fact, that is Dragnea's hand!] = Dragnea is a thief and he steals from Timmermans' pocket.

4. Ca să nu-i bage Dragnea din reflex 10 lei! [He keeps his hand like this so that Dragnea doesn't put 10 lei inside out of the reflex!] = Dragnea is accused of bribery so he will bribe Timmermans as well. 
5. Sitie că Dragnea îşi face bine meseria. [He knows that Dragnea does his job well.] = Dragnea is a professional thief, and Timmermans keeps his hand in his pocket to protect himself.

\section{Conclusions}

At the level of social relations, we found a connection between decoding insults and their contextual elements (age and sex of interactants, number of participants (active/passive), socio-professional status, level of formality, symmetry/asymmetry of interactional roles).

For a verbal act to fall into the category of insults, it must meet two essential conditions: (1) the speaker intentionally attacks the image of the hearer and (2) the hearer decodes this verbal behaviour as an attack on his public image.

In addition to conflictual contexts, in which insults have a dysphemic character and an offensive illocutionary point, the corpus under analysis also revealed contexts in which insults have phatic functions and signal a social/affective closeness between speakers (see \$3.1.1.2, insults with positive illocutionary point).

\section{Bibliography}

Bacot, P. (2007). Laurence Rosier, Petit traité de l'insulte, in “Mots. Les langages du politique”, 84, p. 116-119, Crossref. Bourdieu, P. (1982). Ce que parler veut dire. Léconomie des échanges linguistiques, Fayard, Paris.

Brown, P. \& Levinson, S. (1987). Politeness: Some Universals in Language Use, Cambridge University Press, Cambridge.

Brenes Peña, E. (2009). La agresividad verbal y sus mecanismos de expresión en el español actual, Teză doctorală susținută la Universidad de Sevilla, [online].

Chevalier, Y.H. \& de Chanay, C. (2009). Savoir être insulteur, ou les marqueurs non verbaux de l'insulte: quelques exemples de "pédé", in Dominique Lagorgette (ed.), Les Insultes en français: de la recherche fondamentale à ses applications (linguistique, littérature, histoire, droit), Université de Savoie, Chambéry, p. 45-74.

Felecan, D. (2014). Pragmatica numelui și a numirii neconvenționale: de la paradigme teoretice la practici discursive, Editura Mega, Argonaut, Cluj-Napoca.

Felecan, D. (2016). Injurătura - automatism verbal. Premise ale cercetării, in "Buletin Științific", Fascicula Filologie, Seria A, Volumul XXV, UTCN, CUNBM, Baia Mare, [online].

Felecan, D. \& Felecan, O. (2020). Conținuturi implicite în bancurile generate de pandemia Covid-19: repere teoretice (I), in "Philologica Jassyensia", XVI (2), p. 265-271, [online].

Fine, G. A. (1981). Rude words. Insults and Narration in Preadolescent Obscene Talk, in "Maledicta", 5, p. 51-68.

Ganea, A. (2007). Insulte, invective, injurii. Forme lingvistice grosiere în romînă şi francezăa, in "Buletinul Institutului de Filologie Romînă A. Philippide”, VIII (3), [online].

Goffman, E. (2007). Viața cotidiană ca spectacol, ediția a II-a (ed. I-a: 1950), Comunicare.ro, București.

Grice, H.P. (1957). Meaning, in "Philosiphical Review”, 66 (3), p. 377-388, Crossref.

Haverkate, H. (1994). La cortesía verbal. Estudio pragmalingüistico, Gredo, Madrid.

Ionescu-Ruxăndoiu, L. (2003). Limbaj și comunicare. Elemente de pragmatică lingvistică, Editura All, București.

Kerbrat-Orecchioni, C. (1992). Les interactions verbales, vol. II, Editura A. Colin, Paris.

Kerbrat-Orecchioni, C. (2010). Politesse, impolitesse, "apolitesse", "polirudesse": éléments théoriques et étude de cas, in Denis Jamet, Manuel Jobert (eds), Theoretical Approaches to Linguistic (Im)politeness.

Kerbrat-Orecchioni, C. (2013). Politeness, Impoliteness, Non-Politeness, Polirudeness. The Cases of Political TV Debates, in Denis Jamet, Manuel Jobert (eds), Aspects of Linguistic Impoliteness, Cambridge Scholar Publishing, Cambridge.

Lagorgette, D. \& Larrivée, P. (2004). Interprétation des insultes et relations de solidarité, in "Langue française", 144, p. 83-103, Crossref.

Larguèche, É. (2004). L'injure, la société, l'islam: une anthropologie de l'injure, Édisud, Aix-en-Provence, [online].

Mateiu, I. \& Florea, M. (2012). Les insultes/injures en tant que manifestations d'agressivite verbale, in "Anuarul Institutului de Istorie G. Barițiu” din Cluj-Napoca, Series Humanistica, tom. X, p. 115-132, [online].

Mateo, J. \& Yus, F. (2000). Insults: A Relevance-Theoretic Taxonomical Approach to their Translation, in "International Journal of Translation", 12 (1), p. 97-130.

Searle, J. (1992). Speech Acts, Cambridge University Press, Cambridge, Crossref.

Simpson, P. (2003). On the Discourse of Satire, John Benjamins, Amsterdam, Crossref.

Sperber, D. \& Wilson, D. (1986). Relevance - Communication and Cognition, Blackwell Publishing, Oxford.

Sperber, D. \& Wilson, D. (2000). Truthfulness and Relevance, in "UCL Working Papers in Linguistics", 12, p. 215-254. 
Stenström, A. \& Jörgensen, A.M. (2008). A Matter of Politeness? A contrastive Study of Phatic Talk in Teenage Conversation, in "Pragmatics", 18 (4), p. 635-657, Crossref.

Wilson, D. (2016). Relevance Theory, in Yan Huang (ed.), The Oxford Handbook of Pragmatics, Oxford University Press, Oxford, Crossref.

Zafiu, R. (2003). «Tu» generic în limba romînă actuală, in Pană Dindelegan, G. (ed.), Aspecte ale dinamicii limbii române actuale. Actele colocviului Catedrei de Limba Română, 27-28 noiembrie 2002, vol. II, Editura Universității din București, București.

Žegarac, V. (1998). What is "Phatic Communication"?, in V. Rouchota, A. H. Jucker (eds), Current Issues in Relevance Theory, John Benjamins, Amsterdam, p. 327-361, Crossref.

Žegarac, V. \& Clark, B.. (1999). Phatic Interpretations and Phatic Communication, in “Journal of Linguistics”, 35 (2), p. $321-$ 346, Crossref.

Zvirid, R. (2013). Actele verbale expresive în limba romînă, Editura Universității din București, București. 